\title{
BALD EAGLE MIGRATION THROUGH SOUTHERN SASKATCHEWAN AND MANITOBA AND NORTH DAKOTA
}

JON M. GERRARD, Box 113, R.R. 1, Headingley, Manitoba, ROH OJO and DAVID R. M. HATCH, 876 Elizabeth Road, Winnipeg, Manitoba. R2J 1A8

\section{Introduction}

Bald Eagles breed extensively around the lakes and rivers of northern Saskatchewan and northern and eastern Manitoba. ${ }^{49}$ In January and February most of these eagles are found in a wide area of the western United States (Figure 1). ${ }^{3}$ Few are found in Saskatchewan, Manitoba or North Dakota in those months. This area is therefore a good region to study Bald Eagles to learn more about the routes they take on migration. Some years ago we analyzed our sightings for this region, but did not publish our findings, in part because there was some question about their interpretation. Now, with additional observations, especially near Saskatoon, and with observations of eagles carrying radiotransmitters, we have revised the original material to give an overview of Bald Eagle migration through this region. ${ }^{2}{ }^{5} \mathrm{~A}$ comparison is made to the migration of Rough-legged Hawks to emphasize certain differences between these species.

\section{Methods}

Much of the information presented here is based on records for the period 1970-73 as reported to C. S. Houston as compiler of the Northern Great Plains region for American Birds. These sightings were supplemented by observations for southern Manitoba by David Hatch from 1958 to the present, near Indian Head (1963-1974) by Mary Skinner, from the region around Saskatoon for 1961 to 1976 as compiled by J. B. Gollop, along the South
Saskatchewan River in fall by Tom Donald, near Winnipeg from 1933-1982 by Angus Shortt, and scattered observations elsewhere reported by a number of individuals. In addition, Jon Gerrard and his wife, Naomi made field trips across North Dakota on 17 and 18 October 1974 and $16-18$ and 25-28 November 1975. Some more recent observations by the authors and others are also included where these add significant new information.

\section{Results}

\section{Winter distribution of Bald Eagles}

Records for January and February were accepted as representing the winter distribution (Figure 1) in view of the late fall migration of Bald Eagles, and their early return in spring. The number of eagles wintering in the region depends upon the severity of the winter. In a mild winter, at least, occasional widely scattered eagles may be present at sites of open water (e.g. Squaw Rapids, Saskatchewan and Garrison, North Dakota dams) or in upland habitat, particularly in southwestern Saskatchewan.

\section{The Spring Migration}

Bald Eagles and Rough-legged Hawks migrate north across the plains of North Dakota, Saskatchewan and Manitoba in March and April (Table 1). The map in Figure 2 shows concentrations of Bald Eagles along the Missouri, James and Souris rivers in 


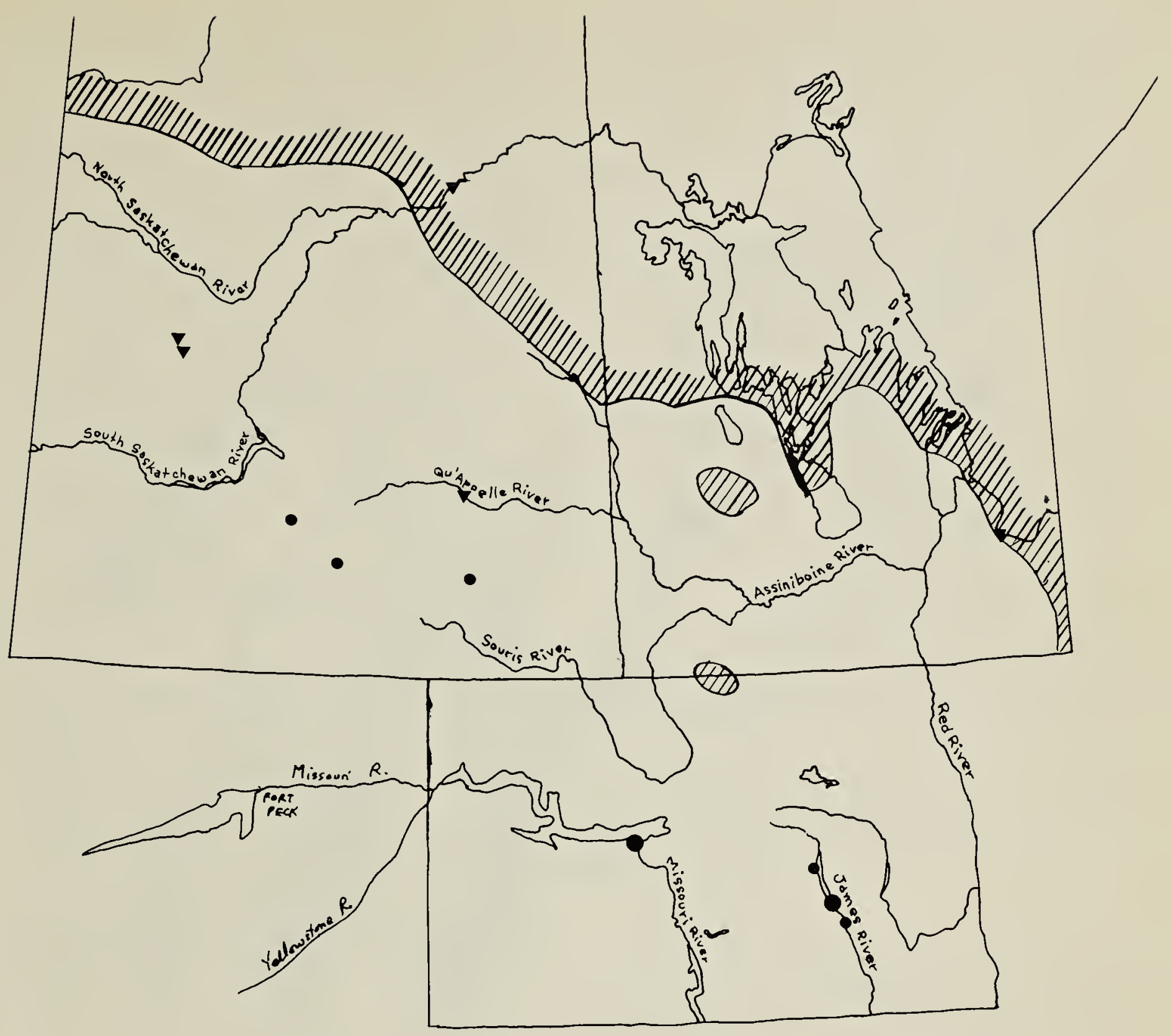

Figure 1: The map shows the approximate current breeding distribution of Bald Eagles (hatched area) plus winter records of Bald Eagles. Winter records for the period 1970-1973 are shown as solid circles. Other winter records are shown as solid triangles. ( $\bullet, \mathbf{\Delta}=1$ or 2 eagles) ( $\bullet=3-6$ eagles).

Table 1. SPRING MIGRATION DATES OF ROUGH-LEGGED HAWKS AND BALD EAGLES

\begin{tabular}{|c|c|c|c|c|c|c|}
\hline & & Earliest & $\begin{array}{l}16 \% \\
\text { by }\end{array}$ & $\begin{array}{l}\text { Median } \\
\text { by }\end{array}$ & $\begin{array}{l}84 \% \\
\text { by }\end{array}$ & Latest \\
\hline $\begin{array}{l}\text { For the } \\
\text { whole } \\
\text { region }\end{array}$ & $\begin{array}{l}\text { Rough-legged Hawk } \\
\text { Bald Eagle }\end{array}$ & * & $\begin{array}{l}\text { Mar. } 31 \\
\text { Mar. } 20\end{array}$ & $\begin{array}{l}\text { Apr. } 9 \\
\text { Mar. } 31\end{array}$ & $\begin{array}{l}\text { Apr. } 25 \\
\text { Apr. } 9\end{array}$ & $\begin{array}{l}\text { May } 16 \\
\text { May } 29\end{array}$ \\
\hline $\begin{array}{l}\text { By } \\
\text { Localities } \\
\text { (Bald Eagles } \\
\text { only) }\end{array}$ & $\begin{array}{l}\text { North Dakota } \\
\text { Indian Head, Sask. } \\
\text { Oak Lake, Man. } \\
\text { Saskatoon, Sask. }\end{array}$ & $\begin{array}{c}\text { * } \\
\stackrel{*}{*} \text { Mar. } 25 \\
\text { Mar. } 11\end{array}$ & $\begin{array}{l}\text { Mar. } 14 \\
\text { Mar. } 26 \\
\text { Mar. } 28 \\
\text { Mar. } 30\end{array}$ & $\begin{array}{l}\text { Mar. } 27 \\
\text { Mar. } 28 \\
\text { Mar. } 31 \\
\text { Apr. } 7\end{array}$ & $\begin{array}{l}\text { Apr. } 7 \\
\text { Apr. } 8 \\
\text { May } 4 \\
\text { Apr. } 13\end{array}$ & $\begin{array}{l}\text { May } 29 \\
\text { Apr. } 23 \\
\text { May } 4 \\
\text { May } 6\end{array}$ \\
\hline
\end{tabular}

*occasional individuals winter 


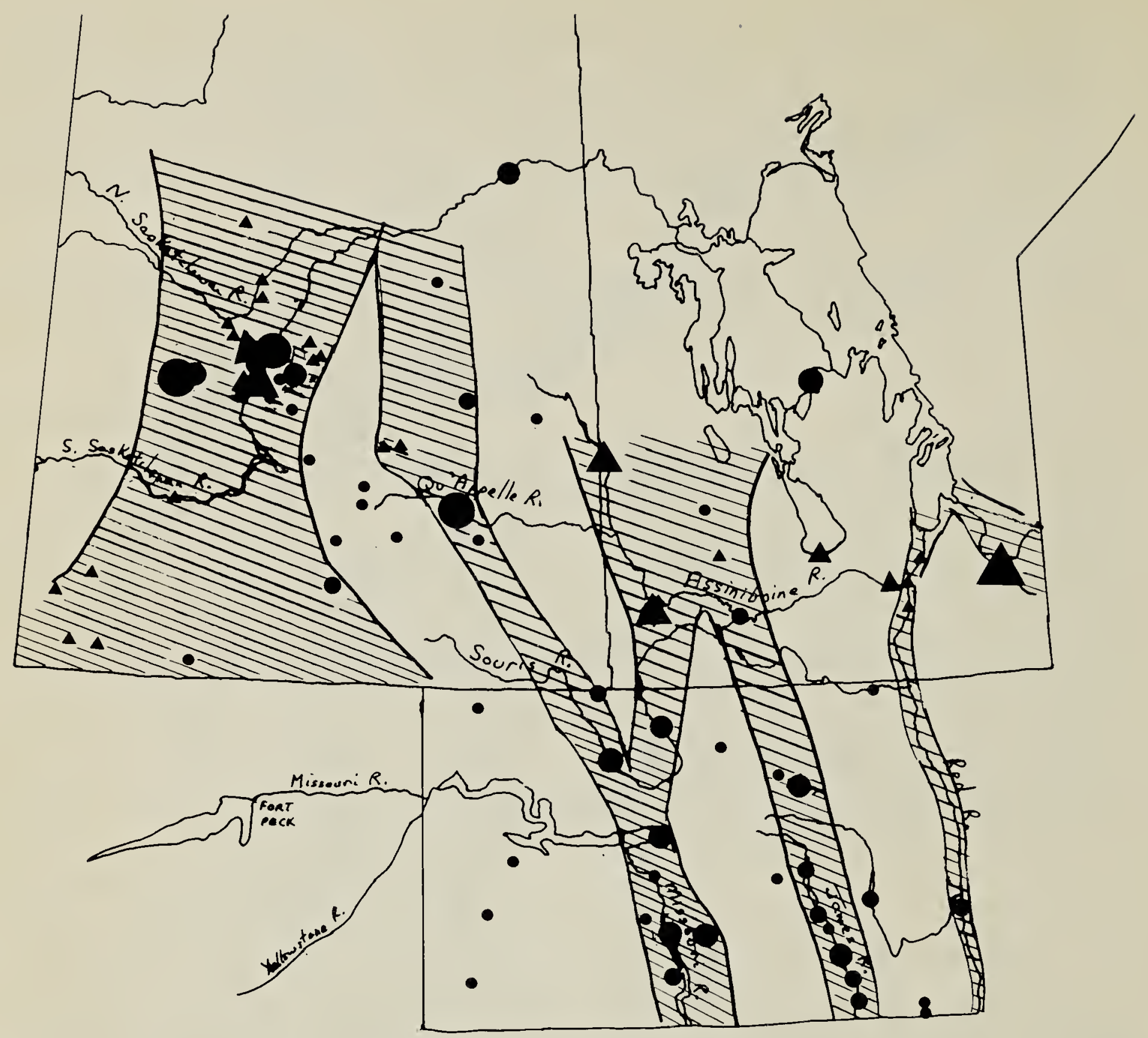

Figure 2: Spring sightings of Bald Eagles for the region. Solid circles refer to records for the period 1970 to 1973. Solid triangles refer to records from other years, which are included only where they add to distribution shown by the solid circles. ( $\bullet, \mathbf{\Delta}=1$ or 2 eagles; $\bullet, \boldsymbol{\Delta}=3-6$ eagles;, $\mathbf{\Delta}=7-14$ eagles, $\boldsymbol{O}$, $\Delta=15$ or more eagles). Hatched regions show what we suspect are the main migration routes.

Table 2. RELATIONSHIP OF SIGHTINGS OF ROUGH-LEGGED HAWKS AND BALD EAGLES WITH LAKES AND RIVERS

\section{Percent (Number) Seen}

Species Near a lake Neara river

Away from a river or lake

$\begin{array}{lllll}\begin{array}{l}\text { Spring } \\ \text { Migration }\end{array} & \begin{array}{l}\text { Rough-legged } \\ \text { Hawk }\end{array} & 1.6 \%(10) & 29.4 \%(187) & 69 \%(439) \\ & \text { Bald Eagle } & 12.9 \%(27) & 59.3 \%(124) & 27.7 \%(58) \\ \text { Fall } & \begin{array}{l}\text { Rough-legged } \\ \text { Hawk }\end{array} & 22.7 \%(29) & 15.6 \%(20) & 61.7 \%(79) \\ \text { Migration } & \begin{array}{c}\text { Bald Eagle } \\ \text { Bald }\end{array} & 32.7 \%(82) & 46.6 \%(117) & 20.7 \%(52)\end{array}$


North Dakota and along the Qu'Appelle and South Saskatchewan rivers in Saskatchewan. There were few sightings of Bald Eagles away from rivers, except for considerable numbers at Valley Center, and between Rosetown and Biggar, Saskatchewan. At Valley Center, "Almost invariably, the eagles will be found in the afternoon of a warm, sunny day when thermals are developing. Unlike most species, they migrate almost straight north in spring (geese, for example usually migrate through heading almost straight west) and at an elevation of 150 to perhaps 350 feet." (W. Renaud pers. communication). In contrast to the Bald Eagle migration, large numbers of Rough-legged Hawks are seen away from the rivers. Nevertheless, some Rough-legged Hawks do migrate along rivers as attested by the sighting of 90 Roughlegged Hawks on 7 and 8 April 1971 , along the Qu'Appelle River Valley north of Indian Head. These birds were flying quite low along the southern valley bank going steadily northwest along the valley using slope lift resulting from an east wind.

We evaluated the difference between sightings of Rough-legged Hawks and Bald Eagles statistically (Table 2) and found the preference of Bald Eagles for rivers during spring migration was highly significant $\left(X^{2}=156, D F=4, P\right.$ $<0.001)$, when compared with the distribution of Rough-legged Hawks. Studies near Saskatoon and of eagles tracked in migration have now shown that the preference of Bald Eagles for rivers is primarily a preference for roost sites along the rivers. Though eagles may migrate to some extent along rivers, much of the time eagles migrate across country away from rivers. The routes across country seem to be chosen with particular regard for irregular terrain. The importance of the Missouri Coteau near Rosetown and Biggar was emphasized when 2 eagles with radiotransmitters followed in 1981 by Al Har- mata and John Squires (pers. comm.) passed along this route. Further emphasis on the importance of hilly areas or areas with slightly more relief than the surrounding terrain are sightings of eagles migrating near Spring Valley on the Missouri Coteau, migrating over the Thickwood Hills (J. M. Gerrard and Al Harmata 1981), over the Allan Hills, and in the region north of Brandon in Manitoba. ${ }^{5}$ Observations by Jon Gerrard in 1981 show that thermal streets can form downwind from hills like the Allan Hills in Saskatchewan. The earlier availability of thermals in hilly areas and the formation of thermal streets downwind of hilly regions are probably a major reason why such terrain is chosen. ${ }^{7}$ The presence of fewer observers in such hilly regions, and the possibility that eagles may sometimes fly very high over hilly terrain with good thermals may explain why more eagles are not reported from these regions.

In Figure 2, the broad regions hatched in we suspect represent the main migration routes of Bald Eagles. Many eagles initially move north from North Dakota roosts along the James and Missouri rivers. In Montana, substantial numbers (over two hundred at a time) of eagles may be present along the Yellowstone River in March. ${ }^{8}$ These 3 rivers (plus possibly lake and river areas in north central Minnesota and northwestern Ontario) appear to form the major originating areas for eagles moving into Saskatchewan and Manitoba. A very small movement along the Red River does occur, but the numbers are minimal. For instance, in 50 years of hawk watching near Winnipeg principally at Deer Lodge (now Silver Heights) in the 1930s and more recently in St. Vital, Angus Shortt has only 6 sightings of Bald Eagles compared to thousands of Red-tailed Hawks seen in the same period. The very flat topography along the Red River compared to the other rivers is probably the 
reason for its low use by eagles. In Manitoba, a large movement occurs through Whiteshell Provincial Park, and a significant movement appears to occur through southwestern Manitoba where the Pembina Hills, the Turtle Mountains, the Carberry Sand Hills and Riding Mountain provide more relief to the terrain. Numbers of eagles can be found roosting along the Assiniboine River between Brandon and the Saskatchewan border. Relatively few eagles come north through central Manitoba in the region between Winnipeg and Portage la Prairie as shown by observations of Gerrard near St. Francois Xavier and observations by John Haugh at Delta: ${ }^{6}$ The area is very flat, probably the reason for fewer eagles, however substantial numbers of Rough-legged Hawks sometimes move north through this region as observed by $\mathrm{Dr}$. H. A. Hochbaum, 10 April 1956, when he saw approximately 340 migrating buteos, about two-thirds Rough-legged Hawks and one-third Red-tailed Hawks. Bald Eagles, with a higher wing-loading (Table 3), need stronger thermals for migrating, and such thermals are more consistently generated in terrain with more relief. ${ }^{7}$

In eastern Saskatchewan, significant numbers of eagles pass through the Qu'Appelle River Valley near Indian Head. This location is in line with hills to the south and north including Moose Mountain, Weed Hills, Pheasant Hills, Beaver Hills and Touchwood Hills; this is probably a reason for this route. In western Saskatchewan, numbers of eagles follow the Missouri Coteau as shown by the sightings near the Bear Hills near Rosetown and Biggar, the Cactus Hills near Spring Valley, and the Thickwood Hills. The South Saskatchewan River is a major roosting location. Regina, on a flat plain, has few sightings of eagles in migration compared to Rough-legged Hawks which are common. ${ }^{1}$

\section{The Fall Migration}

In autumn, Bald Eagles and Roughlegged Hawks travel southward predominantly during October, November and early December (Table 4). In the Saskatoon area, Bald Eagles usually migrated on days when maximum daily temperatures were $-5^{\circ}$ to $+4^{\circ} \mathrm{C}$ (Table 5), and migration was more frequent on days when the maximum daily temperature had fallen frum the previous day (Table 6). While the maximum daily temperature for eagle migration in the fall was lower than that in the spring (usually $0^{\circ}$ to $+14^{\circ} \mathrm{C}$ ), $41 \%$ of the Bald Eagles seen near Saskatoon during the period 1967-1975 were seen on days when there was no snow on the ground.

Table 3. WING LOADING IN BALD EAGLES, ROUGH-LEGGED AND REDTAILED HAWKS*

$\begin{array}{llll} & \begin{array}{l}\text { Weight } \\ \text { (grams) }\end{array} & \begin{array}{l}\text { Wing area } \\ \left(\mathrm{cm}^{2}\right)\end{array} & \begin{array}{l}\text { Wing loading } \\ \left(\mathrm{gms} / \mathrm{cm}^{2}\right)\end{array} \\ \text { Bald Eagles (Male) } & 3,920 & 5,601 & 0.70 \\ \text { Bald Eagle (Female) } & 4,540 & 6,014 & 0.75 \\ \text { Red-tailed Hawk (Male) } & 875 & 1,878 & 0.47 \\ \text { Rough-legged Hawk } & 1,110 & 2,592 & 0.43\end{array}$

* Data on the Red-tailed Hawk and Rough-legged Hawk are from Haugh. ${ }^{6}$ Data on the Bald Eagles are from a pair measured at Besnard Lake in 1982. 
Table 4. FALL MIGRATION DATES OF ROUGH-LEGGED HAWKS AND BALD EAGLES

\begin{tabular}{|c|c|c|c|c|c|c|}
\hline & & Earliest & $16 \%$ by & $\begin{array}{l}\text { Median } \\
\text { by }\end{array}$ & $\begin{array}{l}84 \% \\
\text { by }\end{array}$ & Latest \\
\hline $\begin{array}{l}\text { For the } \\
\text { whole }\end{array}$ & Rough-legged Hawks & Aug. 1 & Oct. 11 & Nov. 2 & Dec. 8 & $*$ \\
\hline region & Bald Eagles & Aug. 15 & Oct. 31 & Nov. 10 & Nov. 27 & $*$ \\
\hline $\begin{array}{l}\text { By } \\
\text { localities } \\
\text { (Bald } \\
\text { Eagles } \\
\text { only) }\end{array}$ & $\begin{array}{l}\text { North Dakota } \\
\text { Indian Head, Sask. } \\
\text { Oak Lake, Man. } \\
\text { Saskatoon, Ssak. }\end{array}$ & $\begin{array}{l}\text { Sept. } 4 \\
\text { Sept. } 30 \\
\text { Oct. } 11 \\
\text { Aug. } 15\end{array}$ & $\begin{array}{l}\text { Nov. } 2 \\
\text { Nov. } 8 \\
\text { Nov. } 6 \\
\text { Oct. } 19\end{array}$ & $\begin{array}{l}\text { Nov. } 12 \\
\text { Nov. } 15 \\
\text { Nov. } 11 \\
\text { Nov. } 5\end{array}$ & $\begin{array}{l}\text { Dec. } 5 \\
\text { Nov. } 18 \\
\text { Nov. } 17 \\
\text { Nov. } 14\end{array}$ & $\begin{array}{c}* \\
* \\
\text { Nov. } 20 \\
\text { Dec. } 1\end{array}$ \\
\hline
\end{tabular}

* occasional individuals winter.

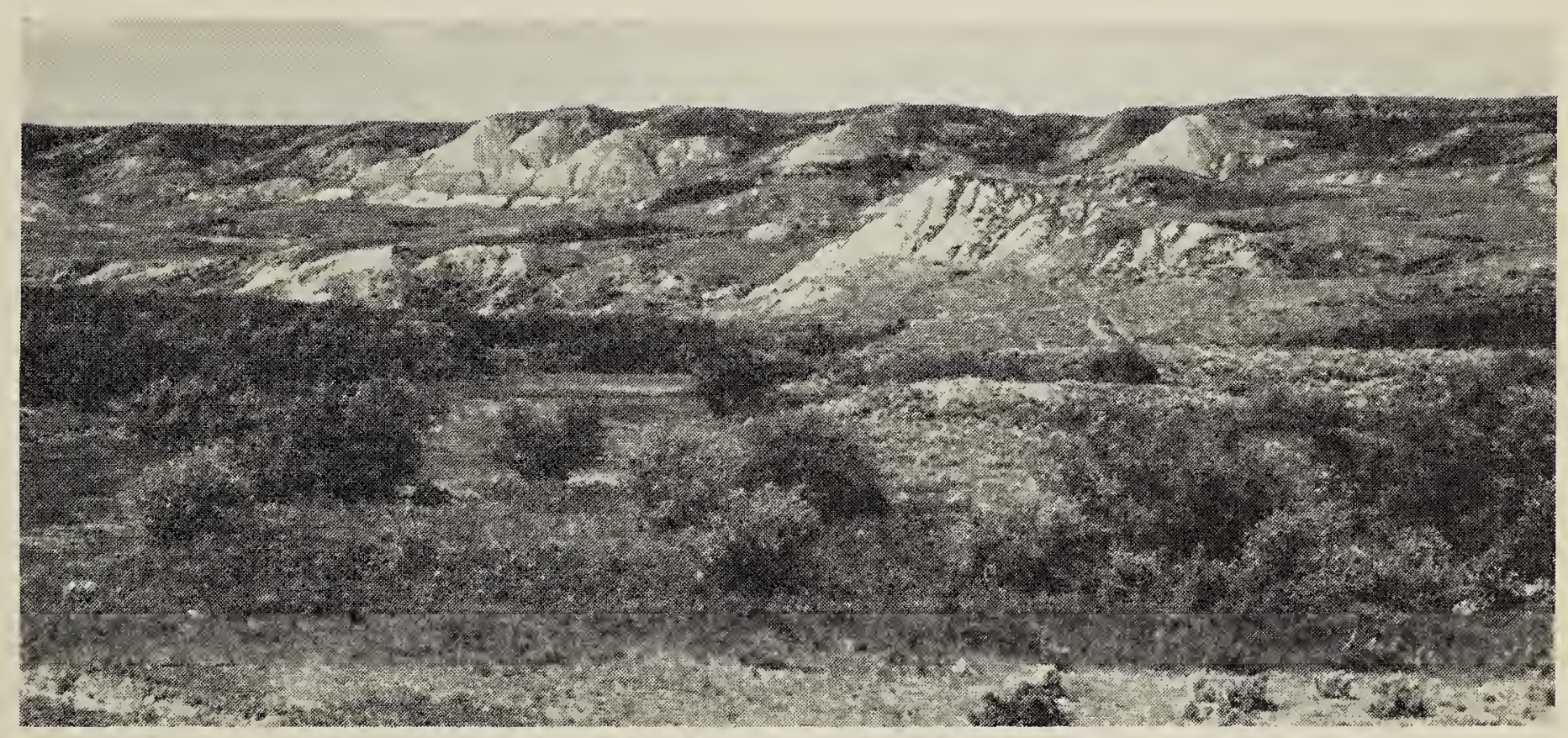

Frenchman River valley.

Gary W. Seib

Table 5. INFLUENCE OF MAXIMUM DAILY TEMPERATURE ON BALD EAGLE FALL MIGRATION

$$
\begin{aligned}
& \begin{array}{l}
\text { Maximum daily } \\
\text { temperature } \\
{ }^{\circ} \mathrm{C} \\
-20 \text { to }-16 \\
-15 \text { to }-11 \\
-10 \text { to }-6 \\
-5 \text { to }-1 \\
0 \text { to }+4 \\
+5 \text { to }+9 \\
+10 \text { to }+14 \\
+15 \text { to }+19 \\
+20 \text { to }+24
\end{array}
\end{aligned}
$$

Number of Bald Eagles seen migrating*

$$
\begin{array}{r}
1 \\
2 \\
1 \\
10 \\
12 \\
3 \\
3 \\
3 \\
0
\end{array}
$$

* data from Saskatoon 1967-75 
Table 6. FALL MIGRATION IN RELATION TO A CHANGE IN THE MAXIMUM DAILY TEMPERATURE OVER THE PREVIOUS 24 HOURS (SASKATOON 1967-1975)

Change in maximum

daily temperature

Increase

Decrease

No Change
No. of eagles seen migrating

12

20
No. of days

213

235

38

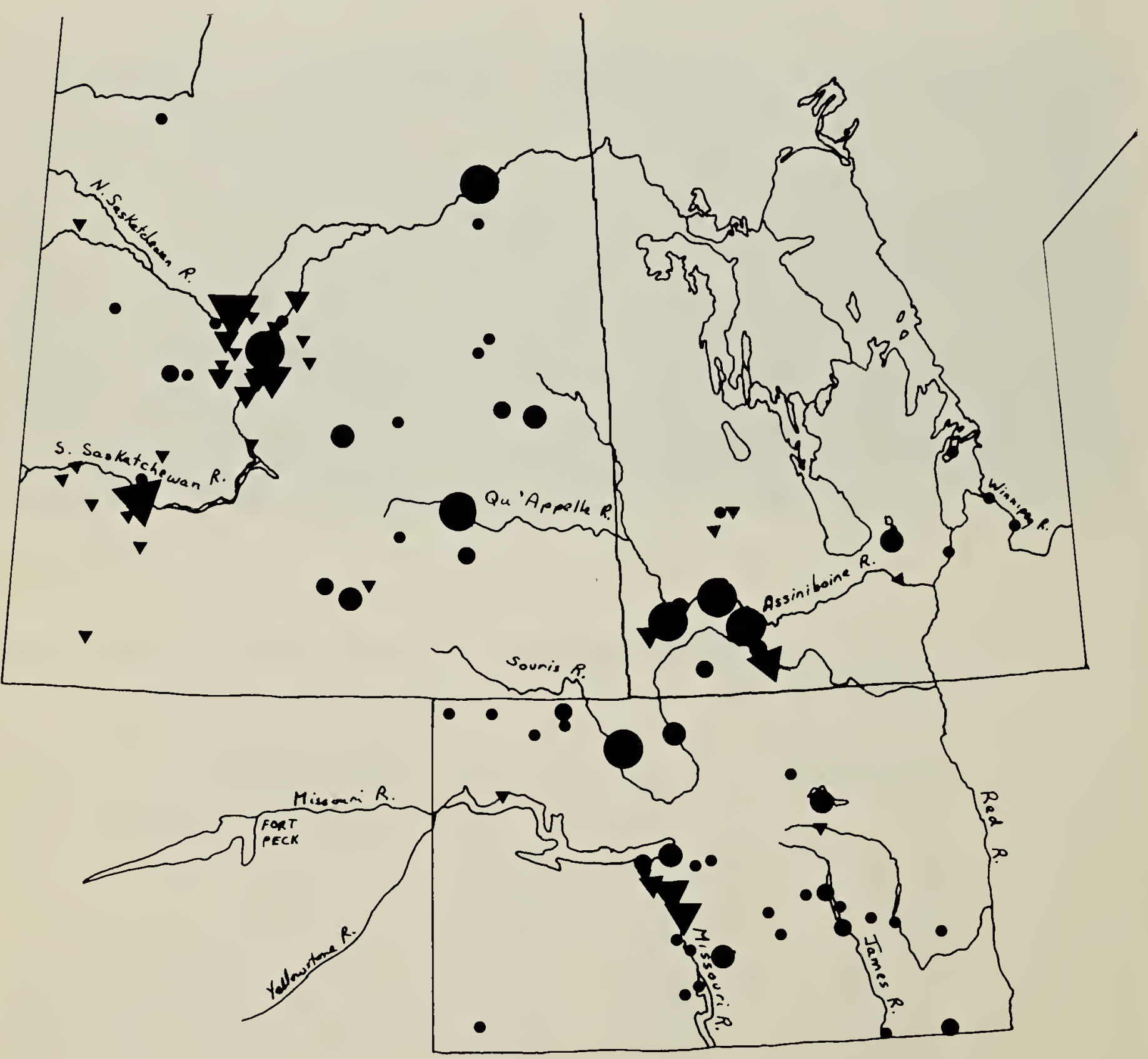

Figure 3: Fall sightings of Bald Eagles for the region. (Symbols are as used in Figure 2.) 
Figure 3 shows concentrations of Bald Eagles along the South Saskatchewan, Qu'Appelle, Assiniboine, Souris and Missouri rivers and at Oak, Devil's, Long, Goose and West Shoal lakes. The location of sightings in fall is similar to that in spring, except that lakes are used much more in the fall. A good example of the fall concentration of eagles near a lake is at Oak Lake; it is a large lake just south of the Assiniboine River in western Manitoba, bordered by trees along the south and east sides with considerable wooded expanses of sandhills nearby. The peak of the fall concentration there coincides closely with the dates of freeze up when there are wounded waterfowl present. Some years Golden Eagles, Snowy Owls and Common Ravens are seen in association with the Bald Eagles around the holes in the ice kept open by the waterfowl. In contrast, Whitewater Lake, the only other large lake in southwestern Manitoba is used to a lesser extent by Bald Eagles. Whitewater Lake is farther from the Assiniboine River (the probable eagle migration route), surrounded by a flat plain with few trees for perches, and there is intensive farming up to the marsh edge. All of these differences; but probably particularly the lack of trees, make this lake less suitable for eagles.

Sightings of eagles at Spring Valley (Cactus Hills), just west of Last Mountain Lake and at Sheho are probably consistent with the trend, in spring, for eagles to choose terrain with slightly more relief. This may also explain, to some extent, migration along rivers which have deep valleys. A striking example of eagles migrating along such a river was noted by $E$. J. Finch whose farm is at the confluence of the Minnedosa and Assiniboine Rivers in Manitoba. On 17 November 1971, a day when there was a strong (about 40 $\mathrm{km} /$ hour) wind from the northwest, 39 or more eagles (about 15 adult Bald Eagles, and the rest predominantly immature Bald Eagles) were seen from
1:15 to $4: 30$ p.m. These eagles came down the Minnedosa River Valley, climbed up to about $600 \mathrm{~m}$ in a thermal associated with slope lift at the mouth of the Minnedosa River, and then glided down arriving very low on the south side of the Assiniboine River before catching an updraft where the wind hit the south bank, and climbing again. In contrast to the considerable numbers of eagles at this site, Bald Eagles are rarely seen along the Assiniboine River near St. Francois Xavier west of Winnipeg. One of only 3 migrating eagles seen at this site in 3 fall seasons was followed for 11 $\mathrm{km}$. The bird, an adult Bald Eagle, circled along the river for $8 \mathrm{~km}$ and had to flap intermittently where the thermals were not strong enough. It travelled along the river for as long as the river went in a southeast direction and then headed south across open farmland. This region, with few eagles, is very flat compared to the region along the Minnedosa and Assiniboine rivers north of Brandon where deep river valleys create much better soaring possibilities.

Most sightings of Rough-legged Hawks (in contrast to those of Bald Eagles) were made away from lakes and rivers (Table 2). We compared the distribution of Bald Eagles and Roughlegged Hawks with respect to their association with lakes and rivers in fall and found that Bald Eagles were much more likely to be seen near lakes and rivers $\left(x^{2}=81, D F=4, p<0.001\right)$.

In order to further evaluate the relationship of Bald Eagles to lakes and rivers in the fall Gerrard spent 9 days travelling in North Dakota during the Bald Eagle and Rough-legged Hawk migration in 1974 and 1975. The association of Bald Eagles with rivers and lakes was confirmed, as was the association of Rough-legged Hawks with areas away from rivers and lakes (Table 7). The association of these large raptors with their particular habitat included not only time spent perching and hunting, but also time spent migrating. 
Table 7. DISTANCE FROM A LAKE OR RIVER OF BALD EAGLES AND ROUGH-LEGGED HAWKS SIGHTED IN NORTH DAKOTA, 1974 AND 1975

\section{Distance from lake or river}

less than 100 yards

Perched Migrating
or
Hunting

\section{Rough-legged}

Hawks

Bald Eagles
2

21
0.

14 more than 100 yards, less than 1 mile

$\begin{array}{cccc}\begin{array}{c}\text { Perched } \\ \text { or } \\ \text { Hunting }\end{array} & \text { Migrating } & \begin{array}{c}\text { Perched } \\ \text { or } \\ \text { Hunting }\end{array} & \text { Migrating } \\ 6 & 2 & 14 & 8 \\ 0 & 0 & 0 & 0\end{array}$

It is our impression that Bald Eagles migrate somewhat lower on fall migration, in general, than during spring migration. The reason may be that eagles tend to migrate on days when temperatures are colder, and frequently when the weather is less ideal for thermals. Many eagles seem to travel at least part of their migration along rivers in the fall. However, it clearly is not possible for eagles to travel from their breeding grounds to their wintering locations solely along rivers, and thus their migration may be characterized to a considerable extent as following rivers where feasible, but deviating from this pattern and taking upland and hilly routes where this is not feasible. Roosting and hunting take place much more in association with lakes in the fall than in the spring as eagles feed on wounded waterfowl, or waterfowl trapped in the ice.

\section{Acknowledgements}

We thank the following individuals for providing eagle records or other assistance at some point during the preparation of this manuscript: $T$. Donald, E. J. Finch, P. N. Gerrard, J. B. Gollop, A. Harmata, C. S. and M.I. Houston, W. E. Renaud, B. Robinson, A. Shortt, M. Skinner, and D. W. A. Whitfield.

' BELCHER, M. 1961. Birds of Regina. Spec.
Publ. No. 3, Sask. Natl. Hist. Soc. Regina, Saskatchewan, 76 pp.

${ }^{2}$ GERRARD, J.M. and P. N. GERRARD. 1981. Spring Migration of Bald Eagles near Saskatoon. Blue Jay 40:97-104.

${ }^{3}$ GERRARD, J. M., D. W. A. WHITFIELD, P. GERRARD, P. N. GERRARD and W. J. MAHER. 1978. Migratory movements and plumage of sub-adult Saskatchewan Bald Eagles. Can. Field-Nat. 92:375-382.

${ }^{4}$ GRIER, J. W. 1977. Quadrat sampling of a nesting population of Bald Eagles. Jour. Wildl. Mgmt. 41:438-443.

${ }^{5}$ HARMATA, A. R. 1981. Winter ecology and spring migration of adult Bald Eagles of the San Luis Valley, Colorado. Proc. Bąld Eagle Days 1981 (T. N. Ingram ed.) pp. 31-40.

${ }^{6}$ HAUGH, J.R. 1972. A Study of Hawk migration in North America. Search Agriculture 2:1-60.

7 STRINGER, E. T. 1972. Foundations of Climatology. W. H. Freeman and Co., San Francisco.

${ }^{8}$ SWENSON, J. E. 1983. Is the Northern Interior Bald Eagle Population in North America increasing? In The Biology of Bald Eagles and Osprey (D. Bird et al. eds), Montreal.

${ }^{9}$ WHITFIELD, D. W. A., J. M. GERRARD, W. J. MAHER and D. W. DAVIS. 1974. Bald eagle nesting habitat, density and reproduction in central Saskatchewan and Manitoba. Can. Field-Nat. 88:339407. 